\title{
Pengujian Bahan Formulasi MsNPV ( Mythimna separata Nuclear Polyhedrosis Virus) terhadap Ulat Grayak Padi, Mythimna separata Walker di Lapangan
}

\author{
TRISNANINGSIH DAN ARIFIN KARTOHARDJONO
}

\author{
Balai Besar Penelitian Tanaman Padi \\ (diterima September 2008, disetujui Januari 2009)
}

\begin{abstract}
Study on Material Formulation of MsNPV to Rice Army Form Mythimna separata Walker in the field. The objective of these studies were to observe efficiency material formulations of $M s \mathrm{NPV}$ and the influence to rice plantation on different locations (Indramayu ( $3 \mathrm{~m}$ above sea level), Sukabumi (400m above sea level) and Bogor ( $250 \mathrm{~m}$ above sea level) to larvae of rice army worm. This study used randomized block design with 4 treatments consisted of 3 formulation materials (talc, kaolin and gypsum) and control in five replications. Observations were done to life and death larvae on $5,10,15$ days after inoculation and leaf damaged. Data were analysed with DMRT. Results from this study indicated that material talc formulation was more effective because all the material was dissolve as compare to material kaolin and gypsum formulations while the material were precipitated. Utilize these three material formulations on three different locations above sea level gave the same impact to the mortality army worm larvae and also to the plant damage.
\end{abstract}

KEY WORDS: Rice, army worm, material formulations of $M s \mathrm{NPV}$

\section{PENDAHULUAN}

Dalam dasawarsa terakhir produksi padi telah mengalami kelandaian (Drajat et al. 2001). Pertanaman padi di lapang selalu diserang oleh berbagai macam hama utama maupun potensial. Hama utama yang sering menyerang adalah penggerek batang, wereng dan tikus. Hama potensial yang serangannya kadang-kadang besar, mendadak dan dapat menyebabkan tanaman menjadi puso adalah ulat grayak padi (UGP), Mythimna separata, (Lepidoptera: Noctuidae). Serangannya berat jika musim kemarau lebih awal dari biasanya atau musim kemarau muncul pada musim penghujan (Kalshoven 1981). Serangan pada periode 1989 - 1999 berkisar antara 5,290 ha sampai 23,807 ha, sedang tahun 2002 sekitar 12,114 ha. Serangan terluas pada tahun 2002 terjadi di Sulsel 2,448 ha dan Jabar 2335 ha (Direktorat Bina Perlintan 2003).

Upaya untuk mengendalikan UGP dilakukan secara kimiawi, tetapi cara ini tidak ramah lingkungan karena dapat mencemari pertanaman sekitar- 
nya. Salah satu cara pengendalian ramah lingkungan yang dapat dilakukan adalah dengan menggunakan agens hayatinya. Ulat grayak padi memiliki beberapa agens hayati yang berupa parasitoid, predator dan patogen (Kalshoven 1981). Beberapa patogen yaitu Metarhizium dan Beuveria serta Mythimna separata NPV (MsNPV) efektif terhadap hama ini (Arifin et al. 1989). Patogen yang berupa virus bersifat spesifik inang sehingga tidak akan berpengaruh terhadap serangga atau organisme yang bukan inangnya. Menurut Thompson \& Steinhaus (1950) dalam Hall (1973), penggunaan virus polyhedrosis untuk mengendalikan ulat alfalfa di lapangan jika sudah tampak kerusakan, umumnya terlambat. Pengendalian akan efektif sejak ulat menetas dari telur sampai populasi tinggi. Selanjutnya, Steinhaus (1973) mengemukakan bahwa polyhedra virus akan tetap aktif selama beberapa tahun, bahkan pada suatu kasus dapat mencapai 25 tahun atau lebih lama lagi. Penggunaan patogen serangga memiliki kelemahan, yaitu keadaan lingkungannya (kelembaban dan suhu) harus sesuai. Aplikasi pada lingkungan yang tidak sesuai dalam kondisi hujan dan radiasi sinar ultra violet menyebabkan patogenisitasnya menurun (Watson et al. 1976). Dari pengamatan keefektifan MsNPV terdahulu di Laboratorium menunjukkan bahwa suspensi $10^{5}$ PIB sampai
$10^{9} \quad$ PIB efektif menyebabkan mortalitas larva ulat grayak yang tinggi (Kartohardjono \& Arifin 2007). Oleh karena itu perlu di carikan bahan formulasi $M s \mathrm{NPV}$ agar efisien dan efektif untuk mengendalikan ulat grayak padi.

Penelitian ini bertujuan untuk mengetahui : 1) penggunaan bahan formulasi $M s \mathrm{NPV}$ yang efisien yaitu menggunakan bahan formulasi yang sudah siap pakai lebih mudah dan lebih tepat dari pada membuat suspensi terlebih dahulu, dan effektif yaitu menyebabkan mortalitas larva lebih besar dibanding kontrol. 2) pengaruh beberapa bahan formulasi $M s \mathrm{NPV}$ terhadap UGP pada lingkungan pertanaman padi pada ketinggian yang berbeda (Sukra, Indramayu mewakili daerah pantai; Leuwiliang Bogor mewakili daerah sedang dan Cikembar Sukabumi mewakili daerah pegunungan).

\section{BAHAN DAN METODE}

Penelitian pengujian bahan formulasi dilakukan pada pertanaman padi di lapangan pada MH 2004-2005. Penelitian dilakukan di tiga lokasi dengan ketinggian yang berbeda di atas permukaan laut yaitu Sukra, Indramayu (3 m dpl); Leuwiliang, Bogor (250 m dpl) dan Cikembar, Sukabumi (400 m dpl). Teknik budidaya tanaman padi yaitu jarak tanam, pemupukan, penyiangan pengairan dilakukan sesuai dengan 
anjuran dan tidak diaplikasi dengan insektisida. Pertanaman padi yang digunakan adalah varietas Ciherang dengan luas areal seluruhnya $800 \mathrm{~m}^{2}$, pada setiap petak perlakuan seluas 200 $\mathrm{m}^{2}$. Perlakuan yang dicobakan yaitu tiga bahan formulasi.

Cara pembuatan formulasi, suspensi dan perbanyakan NPV serta cara memperbanyak larva ulat grayak padi menggunakan metoda sebagai berikut. Perbanyakan formulasi MsNPV, sejumlah larva ulat grayak padi (UGP) diletakkan di kotak plastik. Setiap kotak diberi daun padi lalu diaplikasi dengan NPV dosis 2 gram/ 1 air kemudian diinfestasi dengan larva UGP instar 3-4 sejumlah 30-70 ekor. Setiap larva yang terinfeksi NPV dikumpulkan (dipanen). Larva yang terinfeksi dibuat suspensi. Pembuatan suspensi dengan konsentrasi Polyhedral yang digunakan $10^{7}$ $\mathrm{PIB} / \mathrm{ml}$. Larva yang terinfeksi diairi 2,5 $\mathrm{ml}$, lalu digerus dengan mortar. Larva yang telah digerus disaring dengan saringan halus (500 mesh) sampai menjadi suspensi. Pembuatan formulasi, komposisi bahan: tetes tebu (molases, $5 \%$ ); talk ( $95 \%$ ). Suspensi yang digunakan $1 / 3$ bagian tetes tebu dan talk. Ketiga bahan tersebut diaduk lalu dikering anginkan semalam (jangan kena sinar matahari), kemudian dihaluskan, selanjutnya disaring dengan saringan sedang sampai terbentuk serbuk formulasi (Trisnaningsih et al. 2006).
Sebagai perlakuan yaitu bahan formulasi yang terdiri dari talk, kaolin, gypsum dan pembanding (air). Aplikasi formulasi dilakukan pada umur tanaman satu bulan dengan dosis formulasi 2 gram $M s \mathrm{NPV} / 1$ air dan volume air $400 \mathrm{l} / \mathrm{ha}$. Pada setiap petak perlakuan, kedalamnya ditentukan unit sample berukuran $1 \mathrm{~m}$ X $1 \mathrm{~m}$ secara diagonal. Rancangan percobaan yang digunakan rancangan acak kelompok (RAK) dengan 4 perlakuan dan 5 ulangan, sehingga setiap petak perlakuan dipergunakan 8 liter volume cairan semprot dengan jumlah formulasi 16 gram $M s \mathrm{NPV}$, (16 X10 $\mathrm{PIB} / \mathrm{l})$. Masing-masing sample percobaan ditutup dengan kain kasa halus dan kedalamnya diinfestasikan 20 ekor larva UGP pada stadia larva instar 3 - 4 hasil perbanyakan di lab. Pengamatan dilakukan terhadap larva yang hidup dan mati pada 5; 10 dan 15 hari setelah infestasi (hsi). Larva yang mati terinfeksi virus tidak bergerak dan tampak adanya gejala virus pada larva tersebut. Sedang larva yang mati karena sebab lain tidak tampak adanya gejala virus. Persentase tigkat kerusakan dinilai dengan rumus sebagai berikut:

$$
\begin{aligned}
& \sum_{\mathrm{I}=1}^{\mathrm{k}}\left(\mathrm{n}_{\mathrm{i}} \mathrm{X} \mathrm{v}_{\mathrm{i}}\right) \\
& \mathrm{P}=\mathrm{Z} \mathrm{N}
\end{aligned}
$$


Keterangan :

$\mathrm{P}$ = tingkat kerusakan daun

$\mathrm{n}_{\mathrm{i}}=$ jumlah daun pada skala ke $\mathrm{i}$

$\mathrm{vi}=$ nilai skala ke $\mathrm{i}$

$\mathrm{Z}=$ nilai skala tertinggi

$\mathrm{N}=$ jumlah seluruh daun yang diamati

Nilai skala:

$0=$ kerusakan $0 \%$

$1=$ kerusakan $1-10 \%$

$3=$ kerusakan $11-30 \%$

$5=$ kerusakan $31-50 \%$

$7=$ kerusakan $51-75 \%$

$9=$ kerusakan $>75 \%$

Nilai mortalitas larva dihitung berdasarkan rumus Abbott(1925) yaitu:

$$
P=\frac{p-c}{100-c} \times 100 \%
$$

$\mathrm{P}=\%$ kematian

$\mathrm{p}=\%$ kematian perlakuan

$\mathrm{c}=\%$ kematian kontrol

Data hasil pengamatan tersebut dianalisis sidik ragam dan dibedakan antar perlakuan dengan DMRT $5 \%$.

\section{HASIL DAN PEMBAHASAN}

Perbedaan ketinggian ketiga lokasi, yaitu Sukra, Indramayu (3 m dpl), Leuwiliang, Bogor ( $250 \mathrm{~m} \mathrm{dpl}$ ) dan Cikembar, Sukabumi (400 m dpl), yang menyebabkan lingkungan fisik seperti suhu, curah hujan dan intensitas cahaya matahari akan berbeda, sedangkan intensitas sinar UV rendah/dapat diabaikan karena diaplikasikan pada sore hari. Hal tersebut tampak adanya variasi pada mortalitas larva karena aplikasi ketiga bahan formulasi $M s \mathrm{NPV}$. Umumnya mortalitas UGP rendah pada pengamatan pertama kemudian meningkat pada pengamatan berikutnya dan pengamatan tertinggi pada 15 hsa (Tabel 1). Tingginya mortalitas pada 15 hsi disebabkan oleh gejala virus NPV yang tampak jelas setelah 2 minggu terinfeksi (aplikasi). Penggunaan larva instar 3 saat infestasi efektif sampai pengamatan 15 hsi. Setelah waktu itu sebagian larva sudah mati dan sebagian lagi menjadi prapupa. Ketiga bahan formulasi (talk, gypsum dan kaolin) MsNPV yang dicobakan menyebabkan mortalitas larva yang nyata dibandingkan dengan kontrol pada pengamatan 15 hsa di ketiga lokasi. Ketiga formulasi yang dicobakan pada pengamatan 15 hsa menyebabkan persentase mortalitas yang cukup tinggi antara $69-93 \%$ dan berbeda nyata dengan kontrol (35 - $42 \%$ ) (Tabel 1). Perbedaan pada kontrol dengan perlakuan terhadap mortalitas larva UGP sekitar 34 - 51\% akibat perlakuan $M s \mathrm{NPV}$ dengan bahan formulasi yang dicobakan. Diantara ketiga formulasi tersebut tampak talk mendapatkan persentase mortalitas yang tertinggi $(77-93 \%)$ dibanding formulasi kaolin $(65-77 \%)$ dan gypsum (69- $75 \%$ ) (Tabel 1). 
Tabel 1. Pengaruh formulasi NPV thd mortalitas ulat grayak padi di tiga lokasi MH 2004-2005(\%)

\begin{tabular}{|c|c|c|c|c|c|c|c|c|c|}
\hline \multirow[t]{2}{*}{ Formulasi } & \multicolumn{3}{|c|}{$5 \mathrm{hsa}$} & \multicolumn{3}{|c|}{$10 \mathrm{hsa}$} & \multicolumn{3}{|c|}{$15 \mathrm{hsa}$} \\
\hline & Sukra & Leuwl & Cikem & Sukra & Leuwl & Cikem & Sukra & Leuwl & Cikem \\
\hline Kontrol & $17.34 \mathrm{a}$ & $3.34 \mathrm{a}$ & $0 \mathrm{a}$ & $36 \mathrm{a}$ & $5.0 \mathrm{a}$ & $20 \mathrm{a}$ & $42.6 \mathrm{a}$ & $35.0 \mathrm{a}$ & $40 \mathrm{a}$ \\
\hline Talk & $22.6 \mathrm{a}$ & $23.9 \mathrm{~b}$ & $26.7 \mathrm{c}$ & $65.4 \mathrm{~b}$ & $56.0 \mathrm{c}$ & $61.3 \mathrm{c}$ & $77.4 \mathrm{~b}$ & $93.3 \mathrm{c}$ & $82.7 \mathrm{~b}$ \\
\hline Kaolin & $14.7 \mathrm{a}$ & $10.7 \mathrm{ab}$ & $6.7 \mathrm{~b}$ & $48 \mathrm{ab}$ & $25.4 \mathrm{~b}$ & $42.7 \mathrm{~b}$ & $74.8 \mathrm{~b}$ & $65.3 \mathrm{~b}$ & $77.3 \mathrm{~b}$ \\
\hline Gypsum & $18.7 \mathrm{a}$ & $12.0 \mathrm{ab}$ & $10.7 \mathrm{~b}$ & $34.6 \mathrm{a}$ & $29.4 \mathrm{~b}$ & $36.2 \mathrm{~b}$ & $69.4 \mathrm{ab}$ & $75.9 \mathrm{bc}$ & $73.3 \mathrm{~b}$ \\
\hline C.V. $(\%)$ & 26.48 & 30.74 & 37.37 & 20.23 & 17.19 & 15.12 & 15.99 & 12.71 & 13.59 \\
\hline
\end{tabular}

Tabel 2. Kerusakan padi oleh UGP pada uji formulasi di tiga lokasi MH 2004-2005

\begin{tabular}{llll}
\hline \hline Formulasi & \multicolumn{3}{c}{ C kerusakan } \\
\cline { 2 - 4 } & Sukra & Leuwiliang & Cikembar \\
\hline Kontrol & $1,8 \mathrm{a}$ & $10 \mathrm{a}$ & $3 \mathrm{a}$ \\
Talk & $1 \mathrm{a}$ & $2 \mathrm{c}$ & $3 \mathrm{a}$ \\
Kaolin & $1 \mathrm{a}$ & $4,8 \mathrm{~b}$ & $3 \mathrm{a}$ \\
Gypsum & $1 \mathrm{a}$ & $4,8 \mathrm{~b}$ & 33,29 \\
\hline C.V. $(\%)$ & 45,6 & 14,18 & \\
\hline
\end{tabular}

Ket.: Data dianalisis dg trans. Arsin Vx. Angka sekolom yang diikuti oleh huruf yang sama tidak berbeda nyata dg DMRT 5\%

Rendahnya persentase mortalitas larva pada formulasi kaolin dan gypsum, antara lain karena formulasi ini tidak langsung larut di air dan masih ditemui adanya endapan. Hal tersebut berbeda dengan formulasi talk yang terlarut dalam air, sehingga penggunaan talk lebih efektif dibanding kaolin dan gypsum. Penggunaan ketiga bahan tersebut tampak efisien karena tidak menyebabkan terjadinya pencemaran pada areal pertanaman padi di sekitarnya. Demikian pula persentase mortalitas UGP diantara ketiga lokasi menunjukkan kecenderungan yang tidak terlalu berbeda. Persentase mortalitas UGP di Sukra berkisar antara 69,4 - 77,4 \%; di Leuwiliang berkisar antara 65,3 - 93,3\%; dan di Cikembar berkisar antara 73,3 - 82,74 $\%$ (Tabel 1).
Pengaruh terhadap kerusakan daun padi di ketiga lokasi juga tidak terlalu bervariasi yang berkisar antara 1-10\%. Di Cikembar terdapat perbedaan nyata antara perlakuan dengan pembanding, sedang di Sukra tidak berbeda nyata. Larva ulat grayak pada siang hari berada pada pangkal tanaman dan baru pada malam hari ke daun untuk makan helaian daun padi sehinga larva tidak lansung terinfeksi $M s$ NPV yang telah diaplikasikan. Gejala larva yang terinfeksi virus baru tampak pada 5 hari setelah aplikasi. Hal tersebut menyebabkan rendahnya persentase kerusakan tanaman. Disamping itu, dalam satu $\mathrm{m}^{2}$ yang ada 16 rumpun tanaman padi diinfestasi dengan 20 ekor larva. Sedang serangan berat akibat ulat grayak pada pertanaman padi di lapangan terjadi apabila ditemukan 11-12 ekor larva per 
rumpun dan serangan sedang 2-3 ekor larva per rumpun dan serangan ringan ditemui kurang dari satu ekor larva per rumpun Ambang ekonomi tercapai pada kepadatan populasi 10,83 ekor per rumpun. (Kartohardjono 2004 ).

Penggunaan tiga jenis formulasi di ketiga lokasi dengan ketinggian berbeda tampak tidak terlalu berbeda terhadap persentase mortalitas larva dan kerusakan tanaman. Oleh karena itu formulasi $M s$ NPV dapat digunakan pada areal pertanaman padi yang berbeda lingkungannya pada lokasi dengan perbedaan ketinggian dari muka laut.

\section{KESIMPULAN}

Berdasarkan atas hasil yang telah diperoleh dapat disimpulkan bahwa :

1. Penggunaan tiga jenis bahan formulasi $M s \mathrm{NPV}$ di tiga lokasi yang berbeda mempunyai pengaruh yang sama terhadap mortalitas larva ulat.

2. Dari tiga jenis bahan formulasi yang digunakan, formulasi talk $M s$ NPV yang lebih efektif karena semua bahan terlarut dibanding dengan formulasi gypsum $M s \mathrm{NPV}$ dan kaolin $M s \mathrm{NPV}$ yang bahannya terjadi endapan pada larutannya.

\section{DAFTAR PUSTAKA}

Direktorat Bina Perlindungan

Tanaman. 2003. Evaluasi Serangan Organisme Pengganggu
Tanaman Padi. Dir.Jen.Tan. Pangan dan Horti.Jkt.

Darajat AA, Suwarno B, Abdullah, Suwito ZA. Simanulang. 2001. Status penelitian pemuliaan padi untuk memenuthi kebutuhan pangan masa depan. Makalah pada Apresiasi di Sukamandi, 26 Juli. $20 \mathrm{~h}$

Hall IM. 1973.Use of Micro-organism in Biological Control. In Biological control of insect pests and weeds. Edited by P. DeBach: 610 - 628. Chapman and Hall Ltd. London

Kalshoven LGE.1981. Pests of crops in Indonesia. PT Ichtiar Baru-van Hoeve Jakarta

Kartohardjono A. 2004. Beberapa Cara Pengendalian Ulat Grayak, Mythimna separata Pada Tanaman Padi Sawah. Prosiding Seminar Nasional Entomologi dalam Perubahan Lingkungan dan Sosial. Bogor 5 Oktober: 585 - 598

Kartohardjono A, Arifin M. 2007. Control of rice army worm using virus formulation $M s \mathrm{NPV}$ on rice. Proceedings ICCS. Brawijaya Univ, Malang, Indonesia, Sept $20^{\text {th }}-22^{\text {nd }}, 2005: 56-59$

Steinhaus EA. 1973. Microbial Diseases of Insect. In de Bach (ed.) Biological control of insect pests and weeds: 515 - 547. Chapman and Hall Ltd. London

Trisnaningsih, Kartohardjono A, Cece Sukmana. 2006. Formulasi NPV(Nuclear Polyhedrosis Virus) untuk mengendalikan ulat grayak padi, Mythimna separata. Laporan DIPA Th 2005. BALITPA. 